\title{
PERAN SUAMI MEMPERCEPAT PROSES PERSALINAN ISTRI
}

\author{
Zulfita1, Novria Hesti², Irma Isra Hayati ${ }^{3}$, Chici Ananda Putri ${ }^{4}$, Sena Pebrina ${ }^{5}$ \\ 1,2,3,4,5 Prodi Kebidanan Program Sarjana dan Pendidikan Profesi Bidan Program Profesi STIKes \\ MERCUBAKTIJAYA Padang
}

E-mail korespondensi : novriahesti@gmail.com

\begin{tabular}{l}
\hline Article History: \\
\hline Received: 30 Maret 2021 \\
Revised: 31 Maret 2021 \\
Accepted: 30 April 2021
\end{tabular}

Kata Kunci : Peran Suami, Proses Persalinan
Keywords: husband's role, labor process

\begin{abstract}
Abstrak:
Latar Belakang : Pendampingan suami saat persalinan mempunyai peranan penting bagi ibu karena dapat mempengaruhi psikologis ibu. Kondisi psikologis yang nyaman, rileks dan tenang dapat terbentuk melalui dukungan kasih sayang keluarga. Kelurahan Anduring merupakan salah satu kelurahan yang ada di wilayah kerja Puskesmas Ambacang. Saat ini di Kelurahan Anduring terdapat 37 orang ibu hamil. Permasalahan di kelurahan Anduring saat ini adalah belum ada kelompok khusus suami peduli istri sendiri dimana kelompok ini mempunyai peran penting dalam pross persalinan ibu. Tujuan program ini adalah membentuk kelompok suami peduli istri sendiri, memberikan pelatihan pada kelompok suami dan peningkatan pengetahuan suami tentang peran suami mempercepat proses persalinan istri.
\end{abstract}

Metode : Pembentukan kelompok suami peduli istri sendiri, identifikasi kebutuhan melalui pengumpulan data dan observasi, perancangan kegiatan melalui persiapan dan inisiasi. Pada tahap implementasi kegiatan yang dilakukan adalah pengenalan antar anggota kelompok, pelatihan yang dilakukan langsung kepada suami, pembimbingan dan sosialisasi kepada kelompok suami. Evaluasi pelaksanaan program berkelanjutan dengan pengisian kuisioner dan pembuatan video.

Hasil: Terlaksananya pemberian informasi dan adanya panduan praktis serta praktek langsung peran suami saat mendampingi istri melahirkan. Terbentuknya kelompok Suami Peduli Istri Sendiri yang dilanjutkan melalui Aplikasi WhatsApp Grup, sehingga kesehatan Ibu hamil bisa dipantau bersama.

Abstract:
Background: Husband's assistance during childbirth has an
important role for mothers because it can affect the mother's
psychology. A comfortable, relaxed and calm psychological
condition can be formed through the support of family
affection. Anduring Village is one of the urban villages in the
Ambacang Community Health Center working area. Currently
in Anduring Village there are 37 pregnant women. The
problem in Anduring sub-district currently is that there is no
special group for husbands who care for their own wives,
where this group has an important role in the process of
maternal childbirth. The purpose of this program is to form
husbands who care for their own wives, provide training to
husbands 'groups and increase their knowledge of husbands'
roles in accelerating the process of wife's labor.

Abstract:

Background: Husband's assistance during childbirth has an important role for mothers because it can affect the mother's psychology. A comfortable, relaxed and calm psychological condition can be formed through the support of family affection. Anduring Village is one of the urban villages in the Ambacang Community Health Center working area. Currently in Anduring Village there are 37 pregnant women. The problem in Anduring sub-district currently is that there is no special group for husbands who care for their own wives, where this group has an important role in the process of maternal childbirth. The purpose of this program is to form husbands who care for their own wives, provide training to roles in accelerating the process of wife's labor. 
Method: Methods of implementation: Formation of husband and wife groups, identification of needs through data collection and observation, designing activities through preparation and initiation. In the implementation stage, the activities carried out are introductions between group members, training conducted directly to husbands, mentoring and socialization to husbands' groups. Evaluation of ongoing program implementation by filling out questionnaires and making videos.

Result: Implementation of providing information and practical guidance and direct practice of the husband's role when assisting a wife in childbirth. The formation of the Husband Caring for Their Own Wife group which was continued through the WhatsApp Group Application, so that the health of pregnant women can be monitored together.

\section{Pendahuluan \\ Analisis Situasi}

Kelurahan Anduring merupakan salah satu kelurahan yang terletak di wilayah kecamatan Kuranji Kota Padang dengan luas daerah 4,04 $\mathrm{Km}^{2}$ yang terdiri dari $33 \mathrm{RT}$ dan 8 RW. Kelurahan Anduring berpenduduk 14809 jiwa terdirii dari 6558 laki-laki dan 8251 perempuan. Batas wilayah Kelurahan Anduring adalah sebagai berikut: sebelah Utara berbatasan dengan Kelurahan Lubuk Lintah, sebelah Selatan dengan Kecamatan Padang Timur, sebelah Barat dengan Kelurahan Ampang, dan Sebelah Timur dengan Kelurahan Pasar Ambacang (BPS Kota Padang, 2018).

Hasil wawancara dengan Ketua Tim Penggerak PKK kelurahan Anduring, jumlah ibu hamil di kelurahan Anduring 37 orang. Saat ini sebagian ibu hamil yang ada di Kelurahan Anduring ini, sudah tergabung di kelas Ibu yang diadakan oleh Puskesmas Ambacang. Ibu Hamil ini sudah ada yang mengikuti pertemuan minimal satu kali sebulan, namun yang menjadi masalah di kelurahan Anduring saat ini adalah belum ada satupun kelompok khusus suami ibu hamil, sehingga suami belum bisa melaksanakan perannya dengan baik, salah satunya saat mendampingi istrinya bersalin.

Berdasarkan rekomendasi World Health Organization (WHO) bahwa pendampingan persalinan merupakan pilihan ibu sendiri, namun partisipasi suami dalam kesehatan reproduksi belum optimal, masih banyak suami belum mampu menunjukkan perannya selama proses persalinan. Hal ini dapat mengakibatkan meningkatnya kadar katekolamin yang berlebihan sehingga terjadi penurunan aliran darah ke rahim, kontraksi uterus melemah, menurunnya aliran darah ke plasenta, oksigen yang tersedia untuk janin berkurang serta meningkatnya lama persalinan (Primasnia, P, Wagiyo, 2013).

Pendampingan suami saat persalinan mempunyai peranan penting bagi ibu karena dapat mempengaruhi psikologis ibu. Kondisi psikologis yang nyaman, rileks dan tenang dapat terbentuk melalui dukungan kasih sayang keluarga. Bentuk dukungan bisa berupa support mental, berbagi pengalaman saat menjalani proses persalinan, atau hal-hal positif lain, sehingga berpengaruh pada kekuatan ibu saat melahirkan bayinya 
(Laila, I, 2015). Dukungan suami dalam proses persalinan akan memberikan efek pada ibu yaitu dalam hal emosi, emosi ibu yang tenang yang menyebabkan sel-sel sarafnya mengeluarkanp hormon oksitosin yang reaksinya akan menyebabkan kontraksi pada rahim pada akhir kehamilan untuk mengeluarkan bayi (Hidayati \& Ulfah, 2019). Dukungan minimal berupa sentuhan dan kata-kata pujian yang membuat nyaman serta memberi penguatan pada saat proses persalinan .

Dukungan fisik yang dapat diberikan dapat berupa kontak mata, memegang tangan, dan menggosok punggung (Setyowati \& Mursini, 2017). Bentuk dukungan lain yang dapat diberikan suami adalah advokasi yaitu terkait dengan pengambilan keputusan, pemberian informasi mengenai prosedur dan kemajuan persalinan. Dukungan fisik erat kaitannya dengan tindakan yang dapat meningkatkan kenyamanan ibu selama persalinan. Dukungan ini dapat diberikan dengan memberikan pijatan, mengelus wajah, menggenggam tangan, membantu mengatur nafas, membantu merubah posisi, menemani ibu berjalan-jalan ringan atau bahkan hanya dengan memberikan kontak mata saat memberikan pujian (Simpkin, Penny dan Ancheta, 2013).

Berdasarkan hasil pengamatan tim pengabdi dan hasil wawancara ketua PKK dan kader pada umumnya ibu bersalin diantar oleh suami mereka ke tempat bersalin, namun sampai di tempat bersalin suami tersebut biasanya menunggu di luar ruangan bersalin sambil main handphone, merokok dan aktifitas lainnya. Suami tidak masuk menemani istri ke ruangan persalinan dengan alasan tidak berani, sudah ada mertuanya yang mendampingi. Hal ini juga didukung dari hasil wawancara dengan suami ibu hamil, dari 3 orang suami yang diwawancarai, 2 orang suami tidak mengetahui apa saja yang harus dilakukan saat mendampingi persalinan istrinya, belum pernah mendapatkan informasi tentang perannya dalam mendampngi istri melahirkan, Sehingga saat persalinan, suami hanya berperan mendoakan keselamatan istri dan anaknya.

\section{Permasalahan Mitra}

Permasalahan peran suami saat pendampingan proses persalinan sebagai berikut adalah belum adanya kelompok suami ibu hamil, berdasarkan hasil wawancara dengan suami didapatkan pengetahuan suami tentang peran suami dalam mendampingi istri dalam proses melahirkan masih rendah yaitu 33,3 \%, belum adanya panduan praktis serta yang bisa mengedukasi peran suami mendampingi istri saat proses persalinan, upaya pemberian informasi tentang persalinan, selama ini baru terfokus pada ibu/istri. Saat ini sudah marak kelas ibu hamil, grup WhatsApp ibu hamil, namun belum menyentuh ke pihak suami. Selama ini fokus pihak pemerintahan khusunya pihak kelurahan Anduring, lebih berfokus terhadap kesehatan ibu hamil. Peran suami sama sekali belum disentuh. Belum ada penguatan dari pihak kelurahan terhadap suami yang memiliki istri hamil. 


\section{Jurnal ABDI MERCUSUAR}

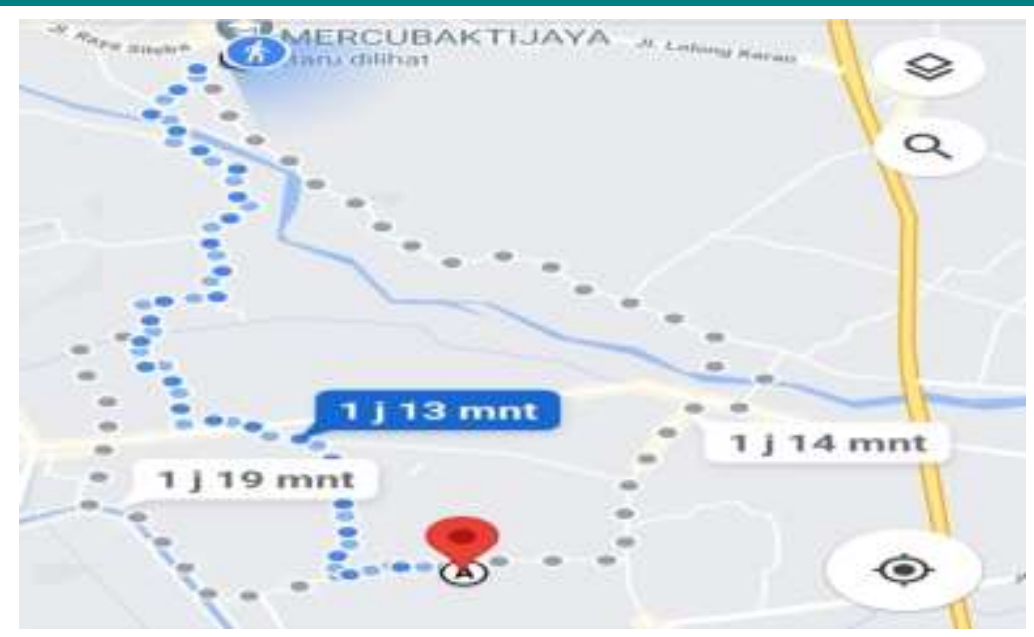

Gambar 1. Peta lokasi pengabdian kepada masyarakat di Kelurahan Anduring

\section{Metode Pelaksanaaan}

Kota Padang

1. Tahap Persiapan

Pada tahap ini dilakukan koordinasi dengan Kelurahan Anduring Padang, Bidan pembina wilayah dan Ketua PKK serta kader untuk membahas kegiatan yang akan dilakukan. Kedatangan tim pengabdi disambut baik oleh pihak Kelurahan. Rangkaian kegiatan pengabdian masyarakat ini, direncanakan akan disepakati pada saat setelah pertemuan dan pembukaan acara kegiatan pengabdian masyarakat tersebut. Kegiatannya antara lain, Pembentukan Kelompok suami peduli istri sendiri, pemberian informasi tentang peran suami mempercepat proses persalinan istri, pelatihan penggunaan panduan praktis pendampingan suami dalam mempercepat proses persalinan istri, disamping itu juga disiapkan instrumen pengabdian yang akan dilakukan seperti berita acara pelaksanaan pengabdian, daftar hadir peserta, doorprize, bahan untuk pelatihan.

\section{Tahap Pelaksanaan}

Pada tahap ini dilakukan beberapa tahap kegiatan yaitu pengisian kuesioner pendampingan suami dalam proses persalinan istri, pembentukan kelompok suami peduli istri, sosialisasi peran suami mepercepat proses persalinan, pelatihan penggunaan panduan praktis peran suami dalam mempercepat proses persalinan istri, pendampingan mitra dalam menggunakan panduan praktis, pemantauan saat mitra dalam menggunakan panduan praktis dan serta evaluasi kegiataan.

\section{Evaluasi}

a. Struktur

Kegiatan pembentukan kelompok suami ibu hamil, dilaksanakan di Ruang pertemuan Kelurahan Anduring. Kegiatan ini dihadiri oleh Lurah Kelurahan Anduring, Dokter Puskesmas Ambacang, Bidan pembina wilayah, Ketua PKK, Kader berjumlah 4 orang. Jumlah sasaran yang hadir pada saat kegiatan pembentukan pembukaan dan pembentukan kelompok tersebut adalah 10 dari 37 pasang suami istri yang memiliki 
istri sedang hamil di trimester 2 dan 3 . Hal ini disebabkan oleh sebagian dari undangan ada yang bekerja, ibu hamil yang sudah mengalami kontraksi dan ada yang sudah bersalin. Setting tempat sudah sesuai dengan rencana yang dibuat sesuai dengan protokol kesehatan COVID 19 dan perlengkapan yang dilakukan untuk pengabdian sudah tersedia dan sudah digunakan sebagaimana mestinya. Pembagian peran antar anggota tim terorganisasi dengan baik. Kegiatan pemberian informasi dan pelatihan penggunaan panduan praktis peran suami dalam mempercepat proses persalinan dengan materi : tanda-tanda persalinan, tanda bahaya pada ibu bersalin, teknik mengurangi rasa nyeri, cara memberikan motivasi pada ibu bersalin, melatih suami teknik mengurangi rasa nyeri persalinan.

b. Proses

Kegiatan pembentukan kelompok suami peduli istri sendiri. Pelaksanaan kegiatan pada hari Kamis, 8 Okober 2021, pukul 13.00 - 15.00 WIB . Sesuai dengan jadwal yang telah direncanakan. Kegiatan ini dihadiri oleh Lurah Kelurahan Anduring, Pimpinan Puskesmas Ambacang, Bidan pembina wilayah, Ketua PKK, Kader berjumlah 4 orang. Kegiatan pemberian informasi dan pelatihan penggunaan panduan praktis peran suami dalam mempercepat proses persalinan istri dan pelaksanaan kegiatan pukul 15 . 00 - 17.30 WIB. Sesuai dengan jadwal yang telah direncanakan.

4. Hasil

Terbentuknya kelompok suami peduli istri sendiri, yang diketuai oleh ibu Rani, SE dan dari pihak institusi diketuai oleh ibu Zulfita, S.SiT. M.Biomed. Bentuk kegiatannya adalah pemberian informasi dan pelatihan tentang penggunaan Panduan praktis peran suami dalam mempercepat proses persalinan dengan materi : tanda persalinan, tanda bahaya pada ibu bersalin, teknik mengurangi rasa nyeri, cara memberikan motivasi pada ibu bersalin, melatih suami teknik mengurangi rasa nyeri persalinan. Pembentukan kelompok suami ibu hamil ini juga dilanjutkan dalam WhatsApp Grup Kelompok Suami Peduli Istri Sendiri sehingga kesehatan Ibu hamil bisa dipantau bersama.

\section{Hasil}

Adanya koordinasi dengan tim dan mahasiswa tentang persiapan untuk kegiatan pengabdian mayarakat ini, seperti instrument pengabdian (Panduan Praktis/KIE), administrasi pengabdian, berita acara pelaksanaan pengabdian, daftar hadir, spanduk , leaflet, video dan sebagainya. Koordinasi dengan ibu Tim Penggerak PKK dan kader tentang permasalahan ibu saat persalinan, bagaimana peran suami, fenomena apa yang terjadi serta kapan waktu dan dimana pelaksanaan kegiatan abdimas ini. Terkait dengan keadaan pandemi sekarang ini maka saat pelaksanaan dilakukan dengan mematuhi protokol kesehatan, wajib masker, cuci tangan dan jaga jarak. Persiapan tempat dan waktu kegiatan, Tempat kegiatan pelaksaan adalah di ruang pertemuan Kantor Lurah Anduring. Pelaksaan pengabdian kepada masyarakat ini dilakukan pada hari Kamis 8 Oktober 2020. Persiapan materi pelatihan, Adanya Panduan, video, dan PPT tentang peran suami dalam mempercepat proses persalinan istri. 


\section{Jurnal ABDI MERCUSUAR}

Vol. 01, No. 01, Mei, 2021, pp. 001 - 010

Pelaksanaan pengabdian di awali dengan pembukaan kegiatan yang dihadiri oleh Lurah, Pimpinan Puskesmas Ambacang, Ketua PKK, kader dan pasangan suami dan istri. Pada saat pelaksanaan kegiatan ini di dapatkan: Teridentifikasinya ibu hamil yang memiliki kehamilan resiko tinggi, yaitu hamil yang ke 5, tapi semua anak meninggal dalam kandungan sebelum dilahirkan. Ibu hamil langsung di rujuk ke RS Mutiara Bunda untuk penanganan selanjutnya.

Terlaksananya model pemberian informasi lansung dan melalui media video serta praktek langsung peran suami saat mendampingi istri melahirkan. Pada saat pelaksanaan suami sangat antusias dan langsung mencobakan ke istri mereka. Komunikasi terjalin dua arah, pasangan suami istri terlihat gembira. Peserta terlihat aktif, suasana menyenangkan, terjadinya keakraban antara suami dan istrinya. Transfer pengetahuan berjalan dengan baik sehingga suami mengerti dan paham bagaimana peran mereka nanti saat mendampingi istri melahirkan. Pemberian informasi dan mengajarkan suami langsung tentang teknik pendampingan ini, sangat di apresiasi oleh Kader, lurah, dan dokter Puskesmas karena baru kali ini suami di ajak serta dalam mengikuti kegiatan seperti ini.

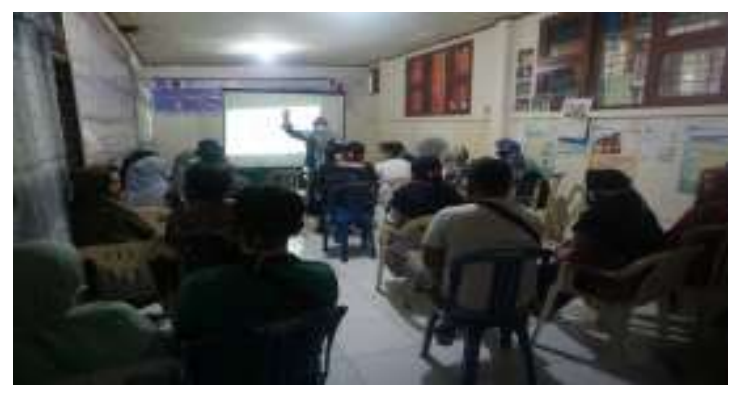

Gambar 2. Pelaksanaan Pemberian materi tentang peran suami dalam proses persalinan

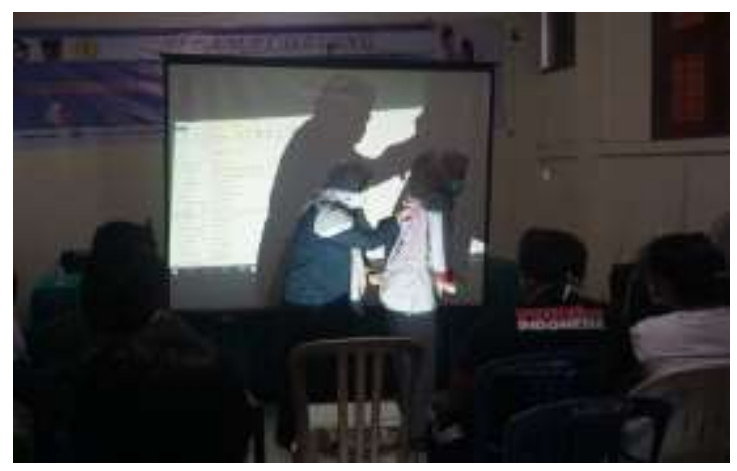

Gambar 3. Demonstrasi salah satu peran suami dalam mengurangi nyeri 


\section{Jurnal ABDI MERCUSUAR}

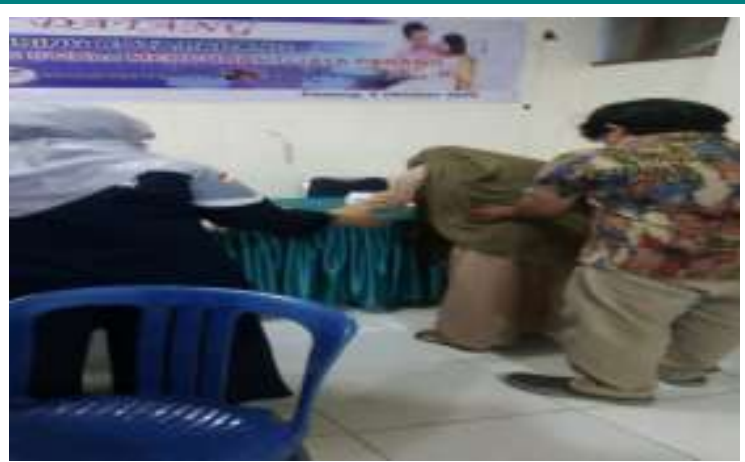

Gambar 4. Foto prakek langsung oleh suami dalam menjalankan perannya sebagai pendamping persalinan istri.

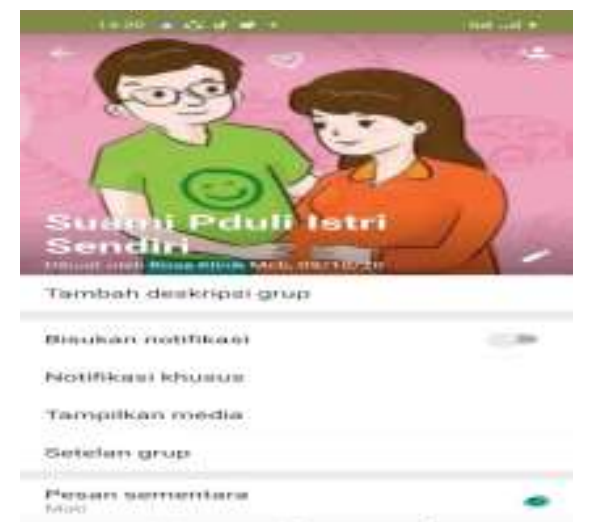

Gambar 4. Foto WhatsApp Grup Kelompok Suami Peduli Istri Sendiri.

Observasi dilakukan terhadap proses edukasi yang dilakukan selama kegiatan pengabdian masyarakat. Evaluasi terhadap keberhasilan kegiatan pengabdian kepada masyarakat ini dengan cara memberikan koesioner sebelum dan sesudah edukasi diberikan. Kuesioner yang di berikan kepada suami ibu hamil sebelum dan sesudah adalah yang sama dengan jumlah soal 10 buah. Koesioner ini diberikan untuk menilai tingkat pengetahuan suami ibu apakah terjadi peningkatan setelah diberikan edukasi. Hasil dari koesioner yang diberikan adalah sebagai berikut :

Tabel 1. Distribusi Frekuensi Karakteristik Sasaran

\begin{tabular}{cccc}
\hline No & Umur & Pekerjaan & Pendidikan \\
\hline 1 & 25 & Buruh & SMP \\
2 & 26 & Sopir & SMA \\
3 & 38 & Bengkel & SMA \\
4 & 33 & Satpam & SMA \\
5 & 22 & Buruh & SMP \\
6 & 35 & Buruh & SD \\
7 & 48 & Buruh & SMA \\
8 & 35 & Jualan & SMA \\
9 & 32 & Buruh & SMA \\
10 & 35 & Buruh & SMA \\
\hline
\end{tabular}


Berdasarkan tabel 1. didapatkan dilihat bahwa tingkat pendidikan sasaran, paling tinggi adalah SMA dan ada yang hanya sampai SD. Hampir sebagian pekerjaan sasaran adalah buruh.

Tabel 2. Score Pengetahuan Suami Pre dan Post Edukasi Peran suami

\begin{tabular}{cc}
\hline \multicolumn{1}{c}{ Score Pengetahuan } \\
\hline Pre Edukasi & Post Edukasi \\
\hline 5 & 7 \\
6 & 8 \\
9 & 9 \\
6 & 10 \\
5 & 7 \\
2 & 6 \\
8 & 8 \\
7 & 9 \\
2 & 8 \\
7 & 10 \\
\hline
\end{tabular}

Berdasarkan tabel 2. dapat dilihat bahwa terdapat peningkatan score pengetahuan suami setelah diberikan edukasi. Beberapa kegiatan yang akan memberikan potensi berkelanjutan dari kegiatan pengabmas ini adalah sebagai berikut adanya perjanjian kerjasama dengan kelurahan Anduring untuk pengembangan kegiatan kelompok suami peduli istri sendiri. Terbentuknya kelompok suami peduli istri sendiri sehingga memudahkan ibu untuk mengikuti kegiatan penyuluhan yang dilaksanakan oleh tim pengabmas dan keterlibatan pimpinan puskesmas dan pembina wilayah, Penggunaan media komunikasi WhatsApp Grup sehingga banyak informasi bisa disampaikan pada grup ini.

\section{Diskusi}

Dari hasil pengabdian masyarakat yang telah dilakukan oleh tim pengabdi, dari yang sebelumnya tidak ada kelompok suami ibu hamil, maka sudah terdapat kelompok suami ibu hamil ini. Selain itu, kelompok ini juga telah dibekali dengan pemberian informasi dan pelatihan tentang, tanda-tanda persalinan, tanda-tanda bahaya pada ibu bersalin, teknik mengurangi rasa nyeri, cara memberikan motivasi pada ibu bersalin, melatih suami teknik mengurangi rasa nyeri persalinan. Dengan adanya kegiatan pengabmas ini masyarakat khususnya suami ibu hamil sudah memahami tentang materi yang diberikan dengan baik, sehingga dapat dilakukan secara berkelanjutan. Dengan adanya informasi terjadi peningkatan pengetahuan suami sehingga akan terjadi perubahan sikap dari suami tersebut, yang awalnya hanya menemani istri melahirkan dengan adanya pemberian informasi ini suami lebih mengetahui perannya dalam mendampingi istri dalam proses melahirkan.

Persalinan merupakan suatu peristiwa penting yang sangat ditunggu oleh setiap pasangan suami istri dan keluarganya. Salah satu yang mempengaruhi persalinan adalah faktor psikologis. Faktor psikologis ini sangat berpengaruh dalam proses 
persalinan dimana seluruh dukungan moral dan material dicurahkan oleh suami dan keluarga bahkan yang bertujuan untuk kesejahteraan ibu dan janinnya. Pada trimester 2 dan 3 atau mendekati persalinan, berbagai perasaan akan dirasakan oleh ibuh hamil seperti rasa cemas, takut, sedih dan atau rasa tidak sabar ingin melihat buah hatinya (Maryumi, 2015). Dukungan yang diterima ibu lingkungan tempatnya melahirkan, sangat mempengaruhi psikologis ibu, maka ibu yang bersalin harus ditemani oleh orang yang dipercaya dan membuat ibu merasa aman yaitu suaminya (Palifiana dan Jati, 2019).

\section{Kesimpulan}

Koordinasi berjalan dengan baik antara tim pengabdi dengan masyarakat di kelurahan Anduring Kota Padang. Sasaran pengabdi memberikan respon yang baik terhadap materi yang telah diberikan, terbentuknya kelompok suami Ibu hamil sehingga memudahkan ibu untuk mengikuti kegiatan penyuluhan yang dilaksanakan oleh tim pengabmas dan adanya panduan praktis peran suami dalam mempercepat proses persalinan istri untuk peningkatan pengetahuan mitra.

\section{Saran}

Diharapkan kepada seluruh panitia yang sudah dibentuk pada kelompok suami peduli istri sendiri ini untuk tetap melanjutkan pemantauan terhadap kesehatan ibu hamil setiap bulan dan dapat juga melalui WhatsApp Grup Kelompok suami peduli istri sendiri, melaksanakan perannya ketika nanti mendampingi istrinya melahirkan sesuai dengan panduan praktis peran suami dalam mempercepat proses persalinan isri yang diberikan. Selain itu, diharapkan dukungan yang penuh tetap diberikan oleh pihak Kelurahan maupun Puskesmas di Kelurahan Anduring Kota Padang, sehingga program ini tetap berjalan dan dapat dikembangkan untuk program pengabdian kepada masyarakat dengan tema yang lainnya sesuai dengan kebutuhan dan permasalahan yang ada.

\section{Ucapan Terimakasih}

Tim pengabdi ingin mengucapkan terimakasih kepada yang terhormat : Yayasan MERCUBAKTIJAYA Padang yang telah memberikan dukungan baik moril maupun materil sehingga kegiatan pengabdian kepada masyarakat ini dapat terwujud. Bapak Lurah Kelurahan Anduring Kota Padang beserta staf, Ketua PKK dan Kader yang telah bersedia menerima tim pengabdi untuk dapat melaksanakan pengabdian kepada masyarakat di wilayah kerjanya serta memberikan dukungan penuh terhadap kegiatan ini. Kepala Puskesmas Ambacang Padang beserta jajaran yang telah bersedia menerima tim pengabdi untuk dapat melaksanakan pengabdian kepada masyarakat di wilayah kerjanya serta memberikan dukungan penuh terhadap kegiatan ini. Seluruh pihak yang terlibat dalam pelaksanaan kegiatan pengabdian ini yang tidak bisa disebutkan satu persatu. 


\section{Daftar Referensi}

Badan Pusat Satistik Kota Padang. (2018). Kecamatan Kuranji dalam Angka. BPS.

Hidayati, T., \& Ulfah, M. (2019). Pengaruh Dukungan Keluarga (Suami) Dengan Lama Persalinan Kala II. Jurnal Keperawatan Dan Kebidanan, 1(1), 8.

Laila, Irma, Nur, N. F. (2015). Pendampingan Suami Terhadap Kelancaran Proses Persalinan di BPM Arifin S Surabaya. Jurnal Ilmiah Kesehatan, Vol 8, No, 22-28.

Maryumi, A. (2015). Nyeri dalam persalinan, Teknik dan cara penanganannya. TIM.

Palifiana, D. A., \& Jati, R. K. (2019). Optimalisasi Peran Suami Sebagai Persiapan Pendamping Persalinan Melalui Prenatal Couple Yoga Di Wilayah Yogyakarta Tahun 2018. Avicenna: Journal of Health Research, 2(1), 1-9. https://doi.org/10.36419/avicenna.v2i1.254

Primasnia Pevi, Wagiyo, E. (2013). Hubungan Pendampingan Suami dengan Tingkat Kecemasan Ibu Primigravida dalam mengahadapi Proses Persalinan Kala I. 212-216.

Setyowati, W., \& Mursini, M. (2017). Hubungan Pendampingan Keluarga Dengan Lama Proses Persalinan Kala I Di Puskesmas Karangdoro Kota Semarang. Jurnal Kebidanan, 6(2), 74. https://doi.org/10.26714/jk.6.2.2017.74-79

Simpkin, Penny dan Ancheta, R. (2013). Kehamilan, Melahirkan dan Bayi. (Edisi Revi). Arcan. 